Christopher Dominguez Michael, Octavio Paz en su siglo

(México: Aguilar, 2015).

RESEÑA

\title{
EL GUARDIÁN DEL SANTO GRIAL
}

\section{David Gallagher}

\section{INTRODUCCIÓN}

\footnotetext{
$\mathbf{E}$
} agosto de 1988, Christopher Domínguez Michael (CDM), el autor de Octavio Paz en su siglo, se incorpora a una renovada mesa de redacción de la revista Vuelta de Octavio Paz (460). CDM en ese momento era un literato de 26 años, y Paz, a los 74, un indiscutido coloso de las letras mexicanas. De allí en adelante, CDM mantiene un diario en que anota su día a día con Paz y el entorno. "Nos cuidábamos mucho de no parecer lo que éramos, biógrafos potenciales del poeta" (504), nos dice; de hecho, otros más, como Enrique Krauze o Guillermo Sheridan, procedieron a escribir importantes biografías de $\mathrm{Paz}_{,}{ }^{2}$ si bien ésta, de CDM, es la más completa. En un ambiente en que hay algo de corte en torno a un monarca que, si bien benévolo, se deja querer y admirar, CDM, quien es, por cierto, un crítico y biógrafo casi del todo exento de vanidad, confiesa: "Mi vanidad me alcanzaba para concebirme como un diminuto Saint-Simon que llevaba la crónica secreta del reino"

David Gallagher. Estudió en la Universidad de Oxford, en la que después fue profesor de literatura latinoamericana y fellow de St. Antony's College. Actualmente es socio de Asset-Chile y combina sus actividades como ensayista con las de la banca de inversiones. Miembro del consejo directivo del Centro de Estudios Públicos. Email: david@assetchile.com.

${ }^{1}$ México: Aguilar, 2015. En adelante nos referiremos al autor como CDM y las citas al libro se identificarán tan sólo con el número de página.

${ }^{2}$ Guillermo Sheridan, Poeta con paisaje (México: Ediciones Era, 2004); Enrique Krauze, El poeta y la revolución (México: Random House, 2014). 
(540). Todo este período, en que nuestro Saint-Simon convive con el monarca hasta su muerte en 1998 (gran final que — como veremos más adelante- él describirá con dramatismo shakespereano), es relatado con especial maestría, porque CDM aprovecha, eso sí que siempre con discreción, las ventajas que le da la intimidad. Pero los 74 años de Paz anteriores a 1988, que inevitablemente abarcan lo grueso de esta magna biografía, son descritos y analizados con el mismo lujo de detalles que los diez años posteriores, en lo que es una obra académicamente impecable, e indispensable para quienes quieren conocer el día a día emocional, literario y político de Paz. Difícil imaginarse un libro mejor documentado y producto de más investigación. Si bien hay períodos en que claramente CDM no ha podido dar con tantas fuentes como quisiera (se le nota mejor informado cuando Paz está en México que cuando está en Cambridge, Inglaterra o Massachusetts, o la India), es difícil concebir un libro más detallado sobre la vida de Paz. Tan detallado que a veces parece estar escrito para iniciados: algunos lectores no mexicanos puede ser que incluso se salten algunas de las descripciones minuciosas que hace CDM de riñas políticas y literarias, todas ellas pródigas en pequeñeces en cuanto a quién excluir o incluir en algún movimiento o en alguna revista o antología. Por otro lado, a mí me hizo falta más atención a la poesía de Paz, que es citada, como para matarla, a renglón seguido, con los versos separados por feas barras. Éste no es un libro para alguien que quiere entender por qué Paz es un gran poeta. Tal vez sea justamente porque es un libro para iniciados. CDM nos cuenta que "Piedra de sol", por ejemplo, "pertenece a la clase de poemas, junto a los de Rimbaud y Neruda, que los jóvenes memorizamos” (249). ¡Eso que tiene 584 endecasílabos! Si es así, si sus lectores preferidos ya conocen los poemas, no es necesario comentarlos mucho, ni importa citar los versos entre barras como estos de "Piedra de sol": "Voy por tu cuerpo como por el mundo, / tu vientre es una plaza soleada, / tus pechos dos iglesias donde oficia / la sangre sus misterios paralelos" (249).

\section{EL JOVEN PAZ}

CDM nos brinda una descripción iluminadora del contexto en que Paz, hijo único, vivió sus primeros años, y nos demuestra cómo ese primer entorno familiar y educativo ha de influir en su vida y obra hasta el final. CDM se detiene primero en el abuelo, don Irineo Paz, un liberal 
masón, "típico republicano del siglo XIX, hombre de espada y pluma" y gran periodista satírico (27): un referente, pienso, para Paz en su lucha posterior para que hubiera en nuestro continente más crítica, más escepticismo, más apertura de mente. Don Irineo era el patriarca de la familia y dueño de la vieja casona en que vivían en Mixcoac. Lo mucho que lo quería Paz se nota en la evocación conmovedora que hará del abuelo en "Cuento de dos jardines", poema aparecido en Ladera este (1962-1968). ${ }^{3}$ Hay allí un afecto profundo, y a la vez la sensación de que el liberalismo que le conoció al abuelo ya era en el mundo un anacronismo, devastado como el jardín de Mixcoac.

Yo era niño

Y el jardín se parecía a mi abuelo.

Trepaba por sus rodillas vegetales

Sin saber que eran los mástiles de un barco

Varado. ${ }^{4}$

Pero tanto o más importante que el abuelo es el padre, Octavio Paz Solórzano, un luchador zapatista que a la vez es un alcohólico empedernido: morirá borracho, arrollado por un tren, en 1936. CDM traza la relación de amor y odio que tenía Paz con su padre, demostrando a través del libro que, con todo, Paz nunca iba a perder su afecto por el romanticismo telúrico que este seguidor de Zapata le había infundido. Y como resume CDM, tanto el padre como el abuelo dejan a Paz inserto en la fuerte tradición anticlerical tanto del México liberal como del revolucionario. "Nieto de un liberal masón e hijo de un revolucionario autor de una hagiografía de Zapata a quien le dio vergüenza decir lo guadalupanos que eran su general y sus tropas, Paz fue, durante toda su vida, un anticlerical y descreído, lo cual lo predisponía para conocer lo sagrado, en buena lid romántica, a través de la poesía” (69). Paz irrumpirá toda su vida en arrebatos anticristianos, como uno notable que cita CDM, de una reseña que hace Paz del Archipiélago Gulag, de Solzhenitsyn. A Paz le espantan las revelaciones del novelista ruso de la crueldad soviética. Pero no resiste el cristianismo de Solzhenitsyn, permitiéndose decir de los cristianos que "no aman a sus semejantes. Y

\footnotetext{
${ }^{3}$ Ladera este (1962-1968) (México: Joaquín Mortiz, 1969).

${ }^{4}$ Ibídem, 131.
} 
no los aman porque nunca han creído realmente en el otro. La historia nos enseña que, cuando lo han encontrado, lo han convertido o lo han exterminado" (407).

\section{LOS AMORES Y EL AMOR}

Paz estudió en el colegio San Ildefonso (tema de uno de sus grandes poemas $)^{5}$ y después en la Escuela de Jurisprudencia, donde, según descubre CDM, fue un estudiante de "extrema irregularidad" (71). Cuando sólo le faltaba aprobar derecho mercantil para licenciarse, abandonó la carrera (71), quemando las naves en lo que ha sido un rito de pasaje para muchos escritores. En 1937, a los 23 años, se casó con Elena Garro, una mujer talentosa pero explosiva que, según CDM, era una gran belleza de la época (digo según CDM, porque he oído voces discrepantes). Paz viajó con ella a España a participar en el Segundo Congreso Internacional de Escritores para la Defensa de la Cultura, que se celebraba en Valencia en julio de 1937. La importancia de este Congreso para las afiliaciones políticas y el pensamiento de Paz la veremos más adelante. Quedémonos por el momento con Elena, o Helena como la tilda Paz, porque pareciera que tiene con ella momentos de incomparable esplendor erótico en este viaje. En "Piedra de sol" (1957), el acto sexual - presumiblemente con ella- disuelve los horrores de la Guerra Civil y, en lo que es un tema recurrente en la poesía de Paz, permite trascender el peso de la historia, permite que la pareja vuelva a un origen edénico anterior a la historia, tocando al hacerlo un instante de éxtasis total, todo mientras cunde la destrucción alrededor.

Madrid, 1937,

En la Plaza del Ángel las mujeres

cosían y cantaban con sus hijos

después sonó la alarma y hubo gritos, casas arrodilladas en el polvo, torres hendidas, frentes esculpidas y el huracán de los motores, fijo: los dos se desnudaron y se amaron por defender nuestra porción eterna,

5 "Nocturno de San Ildefonso", en Vuelta (Barcelona: Seix Barral, 1976), 67-83. 
nuestra ración de tiempo y paraíso, tocar nuestra raíz y recobrarnos, recobrar nuestra herencia arrebatada por ladrones de vida hace mil siglos, los dos se desnudaron y besaron, porque las desnudeces enlazadas saltan el tiempo y son invulnerables, nada les toca, vuelven al principio, no hay ni tú no yo, mañana, ayer ni nombres, verdad de dos en sólo un cuerpo y alma, oh ser total...6

Pero esta mujer en "Piedra de sol" tiene también sus bemoles... no siempre detona este éxtasis vencedor del tiempo. En otra parte del poema, el poeta nos dice de ella - en el supuesto, claro, de que es la misma- que está "armada de navajas invisibles":

Ardo sin consumirme, busco el agua, y en tus ojos no hay agua, son de piedra, $\mathrm{y}$ tus pechos, tu vientre, tus caderas son de piedra, tu boca sabe a polvo, tu boca sabe a tiempo emponzoñado... ${ }^{7}$

Descripción compatible con la que le hace Paz a su amigo José Bianco en una carta que CDM cita, en que le dice que Elena es Artemisa, "la siempre virgen dueña del cuchillo" (76).

Peter Miller, en su traducción al inglés de "Piedra de sol" publicada en $1963,{ }^{8}$ adjunta un intercambio de cartas con Paz. Miller le ha preguntado si el "tu" del poema se refiere a una mujer de carne y hueso, si el poema es entonces, como creen algunos, un gran poema de amor, o si más bien ese "tu" es una "presencia", un "ser sobrenatural", o "un mundo impersonal que para usted se ha vuelto personal". 9 Paz le contesta (y traduzco del inglés) que, si bien hay límites a lo que puede decir

6 "Piedra de sol", en Libertad bajo palabra (México: Fondo de Cultura Económica, 1960), 302.

${ }^{7}$ Ibídem, 299.

${ }^{8}$ Sun-Stone (Toronto: Contact Press, 1963).

${ }^{9}$ Ibídem, 65. 
un autor de su obra, se trata más bien de lo segundo: la "figura central" del poema "aspira a ser una presencia, es decir la encarnación de lo que llamaríamos el lado femenino del mundo". ${ }^{10} \mathrm{Si}$ es así, habría que tener cuidado con tratar de detectar amores reales en el poema; en realidad hay que tener ese cuidado con cualquier poema de cualquier poeta. Pero la respuesta de Paz despierta también un atisbo de escepticismo. En 1963, Paz, hace poco nombrado embajador de México en la India, estaba ya anímicamente muy lejos de Elena Garro. Se había separado de ella definitivamente en 1959, y, antes de eso, tanto Paz como Elena habían tenido un buen número de amantes. ${ }^{11}$ No sorprendería si Paz a esa altura quisiera desaconsejar cualquier reconocimiento de Garro en "Piedra de sol". Sobre todo que en 1962 había conocido a Marie José, quien se consolidará como el amor de su vida gracias a un conmovedor encuentro casual en la Rue du Bac, París, en 1964. Este encuentro lo describe ampliamente CDM (260) y es recogido en ese gran poema que se llama "Viento entero". ${ }^{2}$ Desde que empieza su romance con Marie José, tiende a desaparecer en la poesía de Paz el lado destructivo de la mujer: el "lado femenino del mundo" ya da nada más que placer, éxtasis, trascendencia. Ya no hay más vagina dentata, sino una mujer que acoge al poeta en cópulas vertiginosas que lo conectan por un instante al infinito:

Abajo

El desfiladero caliente

La ola que se dilata y rompe

Tus piernas abiertas

El salto blanco

La espuma de nuestros cuerpos abandonados ${ }^{13}$

En realidad, la presencia de la mujer en Paz es tremendamente física a la vez que trascendente. La mujer en la cópula abre las puertas que dan a la trascendencia pero lo hace abriendo las piernas. En ese gran poema largo que es "Blanco", escrito en 1966 y recogido en Ladera

10 Ídem.

${ }^{11}$ Entre ellos, el novelista argentino Adolfo Bioy Casares, de quien Elena se había enamorado perdidamente hacia 1949 (160).

12 Paz, Ladera este, 101-8.

${ }^{13}$ Ibídem, 105. 
este, en pleno florecimiento de su pasión por Marie José, las cópulas son actos de placer pero también de creación, en que los amantes se autoengendran, convirtiéndose en otros, y a la vez, desde esa vulva que es el lenguaje, engendran la nueva criatura que es el poema. El genio de Paz está en cómo combina lo físico, lo tremendamente sensual, con lo conceptual y metafísico, en lo que es una constante alternancia:

temblor de tierra de tu grupa testigos los testículos solares

lluvia de tus talones en mi espalda falo el pensar y vulva la palabra $^{14}$

Esa "lluvia de tus talones en mi espalda" es el tipo de línea deslumbrantemente sensual que el lector de Paz tiene la suerte de encontrar aun en sus poemas más conceptuales y metafísicos.

\section{EL PAZ POLÍTICO}

Difícilmente se va a encontrar un libro que describa, como éste, con tanta minucia y tanta acuciosidad, el largo y tortuoso viaje que hace Paz desde su cuna en la revolución mexicana y su juventud como simpatizante comunista con intereses anarquistas, al pensador con fama de neoliberal que llega a ser en sus últimos años, si bien en mi opinión en todo este tiempo no cambia tanto, $\mathrm{y}$, como veremos, no llega nunca a ser el hombre de derechas que algunos creen ver en él, ya sea porque buscan denostarlo desde la izquierda, o porque lo quieren reclamar como suyo desde la misma derecha.

Las primeras posturas políticas de Paz, antes del viaje a España en 1937, ya exhiben las contradicciones que han de expresarse en el transcurso de su vida. Porque si bien Paz en esta época es un fervoroso defensor de la república española y de la revolución rusa, nunca se resigna a practicar el arte propagandístico en que insisten los revolucionarios, y mucho menos el árido realismo socialista que propugnan los soviéticos. El mismo Paz recordará, en 1993, en "La letra y el cetro", que en 1935, cuando conoce a su entonces mentor Jorge Cuesta, éste le señala "la disparidad entre mis simpatías comunistas y mis gustos e ideas estéticas y filosóficas" (57). Paz agrega que Cuesta tenía razón, aunque

\footnotetext{
${ }^{14}$ Ibídem, 162-3.
} 
el mismo reproche se pudiera extender, según él, "a Gide, a Breton, y muchos otros, entre ellos, al mismo Walter Benjamin", agregando que "los surrealistas franceses se habían declarado comunistas sin renegar de sus principios" de estética surrealista (57). Cuesta de hecho lo introduce al grupo Contemporáneos, un círculo literario que combina adhesión a la república con, según Paz, el hecho de que "estaban en contra del engagement de los escritores y aborrecían el 'realismo socialista', proclamado en esos años como doctrina estética de los comunistas" (65). Claro que en esa época había quienes sostenían que el poeta verdaderamente revolucionario en política era el que lo era también en su arte, que la revolución política significaba, en consecuencia, revolución estética. Así había sido en la Unión Soviética en los primeros años de la revolución, cuando los vanguardistas rusos pensaban que había llegado su hora de gloria, antes de que Stalin, con sus preferencias estéticas burguesas, impusiera el realismo socialista con, si fuera necesario, la máxima crueldad. En ese sentido, un gran elogio le llega a Paz de Rafael Alberti, en una primera visita a México que hace el poeta español en 1934. Haciendo caso omiso de la nueva estética burguesa-socialista de Stalin, Alberti afirma que "Octavio es el único poeta revolucionario entre ustedes, porque es el único en que hay una tentativa por transformar el lenguaje" (54).

Si Paz, como los surrealistas, con quienes tiene una enorme afinidad, ${ }^{15}$ no se deja contaminar en su propio arte por las ideologías estéticas estalinistas, si en general la política afecta poco a su poesía, cabe preguntarse por qué son tan importantes sus afiliaciones políticas para CDM. La respuesta, claro, es que Paz en México no sólo es un poeta o ensayista; es lo que CDM más tarde llamará un Jefe Espiritual, el referente intelectual más importante que tuvo México en el siglo XX, y por tanto un campo de batalla entre quienes quisieran reclamarlo como uno de los suyos. Por eso son tan importantes, por lo menos para los mexicanos, las posturas ideológicas de Paz a través del tiempo, y por eso CDM las rastrea con tanta devoción en este libro.

15 Para un buen análisis de la relación de Paz con el surrealismo, ver Jason Wilson, Octavio Paz. A Study of His Poetics (Cambridge: Cambridge University Press, 1979), traducido como Octavio Paz. Un estudio de su poesía (Bogotá: Pluma, 1980). Como indica el subtítulo, este libro es también un análisis — excelentede la poesía de Paz en general. 
En España en 1937, Paz se encontró en un campo minado que lo obligó a hacer profundas reflexiones. En el Congreso de Valencia estaban Malraux, Neruda, Alberti, Spender, Aragon, Vallejo, Buñuel, Huidobro, Ehrenburg y muchos otros: la crema y nata de la intelectualidad pro comunista mundial de la época (81-103). Tal vez el hecho más importante es el debate que Paz presenció sobre Gide. Los extremistas lo querían condenar como "enemigo del pueblo español", por un par de libros que Gide ha publicado en 1936 y 1937, donde critica lo que había visto en un viaje a la Unión Soviética (89). El episodio parece haber torturado la consciencia del joven Paz, y más tarde se arrepentiría de no haber levantado más la voz en defensa de Gide (90). Paz nunca fue el mismo después. Luego de presenciar ese dogmatismo matonesco le resultará imposible seguir dándole un apoyo incondicional a la izquierda revolucionaria. Pero su reticencia ante ella no dejó, por muchos decenios, de ser tímida, como lo demuestra una y otra vez CDM. Paz criticaba los errores - sobre todo tras las revelaciones de David Rousset en 1950 acerca de los horrores del socialismo real-, pero a la vez, como para empatar, lanzaba un dardo contra los abusos del capitalismo, y apelaba como ideal a un socialismo puro que algún día triunfaría sobre quienes momentáneamente lo estaban traicionando. Como muchos intelectuales de su época, se resistía a dar un paso más definitivo. Según CDM, "sólo lo dio... al final de su vida", cuando "se definió más como liberal que como socialista, aunque lo animase la fusión futura de ese par de almas divididas de la consciencia occidental" (156). O sea, aun al final de su vida, Paz soñaba con una síntesis, una suerte de tercera vía, que combinara lo mejor del liberalismo y del socialismo; un mundo parriano de izquierda y derecha unidas. Es en parte, como dice CDM, por terror al "paso fatal hacia las tinieblas exteriores, el punto de no retorno" (156), pero también es, creo, por convicción. Cuando es poeta, Paz siempre se la juega: antes de someterla a su arte, le da rienda suelta a su imaginación, tal como uno lo esperaría de un hijo del surrealismo. Pero como pensador es muy cauteloso.

\section{DE 1967 A 1968}

Me permito dar un salto adelante, a las postrimerías de 1967, cuando tuve la suerte de conocer a Paz por primera vez. El tenía 53 años, y 
ya era uno de los grandes poetas de la lengua, equiparable en lo que iba del siglo a Machado, Vallejo, Alberti o Neruda. Había escrito también libros de ensayos de extraordinario peso. En El arco y la lira ${ }^{16}$, con tanta o más autoridad que T. S. Eliot (uno de sus contemporáneos más afines), expuso su poética, exhibiendo de paso una vasta erudición, un incomparable conocimiento de la poesía de sus contemporáneos y antecesores. El laberinto de la soledad ${ }^{17}$ es, en tanto, una reflexión iluminada sobre los orígenes, la naturaleza y la identidad de México y los mexicanos, que se nutre de una tradición de ensayos que, como bien lo dice CDM, se remonta al Facundo de Sarmiento (192) o a las meditaciones sobre el destino de España que florecen con la Generación del 98 (187-188). Por otro lado, en 1967 Paz llevaba unos cinco años como embajador de México en la India y unos tres o cuatro con su queridísima Marie José. No era la primera vez que vivía en la India: había pasado unos seis meses allí como diplomático en 1951-1952. Pero nunca antes se había inmiscuido tanto en la cultura, así como en las religiones hindú y budista, para encontrar en ellas un reflejo de su propia búsqueda de instantes de éxtasis que trasciendan la prisión del tiempo.

Es ése el Paz que yo conocí el 31 de diciembre de 1967, en Londres, en la casa que tenía Carlos Fuentes en Belsize Park (293). ${ }^{18}$ Escribe CDM que, aparte del "anfitrión y su esposa (que por estar indispuesta no bajó a cenar)", estaban "Octavio y Marie José, Guillermo Cabrera Infante y Miriam Gómez, Mario y Patricia Vargas Llosa, el crítico chileno David Gallagher y el narrador mexicano Héctor Manjarrez, con sus esposas y la profesora Jean Franco". (293-294). Yo pensaba que estaba allí también José Emilio Pacheco, pero es posible que haya sido anunciado y que no llegó. Jean Franco estaba, si CDM lo dice: yo parece que la había borrado. Cuenta $\mathrm{CDM}-\mathrm{y}$ quién lo podría olvidarque en esa comida se ofreció "como postre un pastel de chocolate con hachís". Lo habrían traído los Cabrera Infante, a quienes se los había regalado Ben Carruthers. Algunos se molestaron con el "atrevimiento" pero no los Paz, quienes lo tomaron con humor (294).

${ }^{16}$ México: Fondo de Cultura Económica, 1956. Segunda edición, corregida y aumentada, México: Fondo de Cultura Económica, 1967.

${ }^{17}$ México: Ediciones Cuadernos Americanos, 1950.

${ }^{18}$ Belsize, no Belside como lo escribe CDM. 
Unos pocos días más tarde, Paz me invitó a almorzar en Brown's, uno de los hoteles más elegantes de Londres, donde él estaba hospedado. La memoria claro que falla, pero creo tener un recuerdo muy preciso de ese almuerzo. Llego al hotel y no encuentro al poeta hasta que me doy cuenta de que es el señor de traje y corbata escondido detrás de un Wall Street Journal. En el almuerzo, en que Paz, con extraordinaria simpatía, me trata de igual a igual, a pesar de mis 23 años, hablamos sin parar de literatura. Hablamos de Rayuela, en que yo le objeto la obsesión que tiene Cortázar de citar grandes nombres de la cultura una y otra vez, como si necesitara — por inseguro- mostrar su cultura, hacer name dropping a cada rato. Paz me contesta que es lo mismo que hace un Pound o un Eliot. En América, me dice, el escritor es como el conquistador romano: se arroga el derecho de apropiarse de culturas ajenas, y las hace suyas. ¿Por qué tendría Cortázar menos derecho de hacerlo que esos poetas de Estados Unidos? Hablamos de otros escritores argentinos y él elogia La invención de Morel, de Adolfo Bioy Casares. ${ }^{19}$ Hablamos de literatura cubana. Le interesa en especial Cintio Vitier y su grupo Orígenes. Está plenamente consciente, además, de las dificultades que ya tienen los escritores cubanos con el régimen. Yo en ese momento trabajo en el Times Literary Supplement (TLS), y le cuento a Paz que estamos armando un número especial sobre literatura latinoamericana. Le pido que él escriba el ensayo sobre poesía. Accede feliz. ${ }^{20}$ Se queja de la falta de crítica que hay en América Latina, crítica en el sentido amplio de diálogo, de discrepancia creativa, de capacidad para tomar distancia en un continente donde un autor que publica un libro es adulado o descalificado. Por eso me pregunta mucho del $T L S$ y, mirándolo ahora, está ya, tal vez, pensando en esa magnífica revista que él ha de sacar por primera vez en 1971: la revista Plural. ${ }^{21}$ Hablamos de Neruda, con quien, según descubro ahora gracias a CDM, se había dado un abrazo en Londres en un festival de poesía en 1967 (83). Me dice

${ }^{19}$ Años después, supe del romance de Bioy Casares con Elena Garro, lo que demuestra lo generoso que era Paz.

${ }^{20}$ En el ensayo incluirá sus observaciones sobre el escritor latinoamericano como conquistador romano.

21 En 1974, Paz me escribió pidiéndome que colaborara en Plural, con ensayos sobre literatura latinoamericana y, cada tres meses, "un comentario sobre literatura inglesa: poesía, ficción, ensayo, actualidad literaria y, cuando afecte a la cultura, la política". Carta de Octavio Paz, México, 6 de febrero, 1974. Ahora lamento que otros rumbos me impidieran acatar estas gratas instrucciones. 
que le gusta en Neruda la forma en que describe el sonido de pasos que se acercan, $y$, al decirlo, dibuja unos pasos en la mesa con los dedos de la mano ${ }^{22}$.

El año que sigue a este, para mí, inolvidable almuerzo resulta, creo yo, tremendamente ilustrativo de lo que es Paz, por las formas cómo reacciona a los desafíos que el año le trae. Porque 1968 es un año de grandes eventos que algo tienen de común, aunque a primera vista sean, también, contradictorios. Es el año de los grandes sublevamientos estudiantiles, comenzando con los de mayo en París. Es el año en que se consolida el movimiento hippie. Es el año de la primavera de Praga, que desemboca en la entrada a la ciudad de tanques soviéticos. Es el año en que se vuelve evidente, incluso para aquellos que no lo querían ver antes, que en Cuba no hay libertad de expresión, que allí los intelectuales de espíritu libre son duramente discriminados cuando no perseguidos (ese Año Nuevo en la casa de Fuentes estaba, después de todo, el gran Cabrera Infante, ya perseguido por Castro y obligado a exiliarse en Londres). Es el año de la matanza de estudiantes en la Plaza de las Tres Culturas en Tlatelolco, México, que redunda en la renuncia de Paz como embajador en India. Finalmente, es un año de tragedia familiar: como le escribe Paz a Jean-Clarence Lambert, "sucedió algo horrible: la única hermana de Marie José, su marido y su hijo perecieron en un accidente aéreo de Air France entre Córcega y Niza" (313).

Al sublevamiento estudiantil que se inicia en París en mayo de 1968, Paz responde con mucho entusiasmo. Su entonces amigo Carlos Fuentes escribe reportajes eufóricos desde — según él— las mismas barricadas que levantan los estudiantes en su lucha contra la abusiva burguesía capitalista, si bien algunos llegan a dudar de si el a veces fantasioso Fuentes estaba realmente en París. Paz comparte el entusiasmo

${ }^{22}$ Uno podría extraer de este libro de CDM un bonito relato de la relación entre Paz y Neruda. Da la impresión de que sus distanciamientos tuvieron que ver más con riñas literarias, como por ejemplo si se excluía a no a Huidobro —odiado por Neruda - en una antología llamada Laurel, que Paz publicaba en 1940, que a verdaderas disputas ideológicas (118-21). En 1993, Paz, que es gran admirador de "Walking Around", se refiere a Neruda como su "enemigo más querido" (121), y, más emocionante aún, CDM nos revela que Paz tenía en su última agonía a Neruda y Quevedo como autores de cabecera (562). 
de Fuentes. CDM cita una notable carta de Paz al poeta inglés Charles Tomlinson, su amigo, que refleja perfectamente las ideas que le oíamos a Paz en esa época. "Se bambolea el mediocre orden del 'mundo desarrollado'. Me emociona y exalta la reaparición de mis antiguos maestros: Bakunin, Fourier, los anarquistas españoles. Y con ellos el regreso de los videntes poéticos: Blake, Rimbaud, etc. La gran tradición que va del romanticismo alemán e inglés al surrealismo. Es mi tradición, Charles: la poesía entra en acción. Creo que estamos a punto de salir del túnel que empezó con la caída de España, los procesos de Moscú, el ascenso de Hitler, el túnel cavado por Eisenhowers [sic], Johnson y las tecnocracias capitalistas y comunistas nos dijeron que era el camino del progreso y el bienestar" (301). Como se ve aquí, Paz sigue empatando los abusos del comunismo y del capitalismo, y cree que ahora sí puede triunfar ese socialismo ideal que los burócratas soviéticos han traicionado. "Durante esas semanas", escribirá después, "sentí que mis esperanzas juveniles renacían: si los obreros y los estudiantes se unían, asistiríamos a la primera y verdadera revolución socialista. Tal vez Marx no se había equivocado: la revolución estallaría en un país avanzado, con un proletariado madurado y educado en las tradiciones democráticas" (302). Agrega CDM: "Desde allí, confiaba el poeta, se derrumbarían, después del capitalismo, 'los regímenes totalitarios que habían usurpado el nombre del socialismo en Rusia, China, Cuba y otros países"” (302).

Más importante aún, creo yo, que este Paz que ve en París el fin de un capitalismo abusador y el surgimiento del socialismo ideal en que él soñaba, es ese Paz que en la carta a Tomlinson ve como lo más importante de París el romanticismo, el surrealismo y la poesía. Éste es el Paz poeta que en mi opinión nunca cambia; el que en su corazón siempre añora un pasado edénico anterior al vil consumo material, el que siempre sueña con volver a un origen en que el hombre vive en el éxtasis del presente. Es el Paz que en el transcurso de 1968 expresa su admiración no sólo por los estudiantes parisinos, sino también por los hippies. Ambos, según él, rechazan esas tiranías del futuro que imponen el capitalismo y el comunismo, donde el presente es postergado en función de algún día dichoso en que se termine de estudiar o de pagar la hipoteca o de preparar el mundo para los hijos y los nietos. Éste es un 
Paz que en su pensamiento político apela a conceptos de su propia poesía y también a conceptos orientales como de fusión del yin y el yang en instantes extáticos. En esta época, o pronto después, Paz empezará a abrirse también a textos liberales, tales como — según CDM- Tocqueville (329), pero, como dice el biógrafo, aún quiere allí emprender una "conciliación que en el fondo sabe imposible entre el romanticismo y el liberalismo, ya no entre Marx y Rimbaud según sugería el menú surrealista, sino entre Fourier y Tocqueville", para que el progreso nos dé no sólo "más cosas", sino "más ser" (329).

En cuanto a los otros eventos de 1968, no ha de sorprenderse que Paz tuviera una pésima opinión de la acción de los tanques soviéticos contra la primavera de Praga. En cuanto a la revolución cubana, CDM dice que "Paz fue extrañamente frío desde un principio: antes del caso Padilla, salvo un par de elogios de cajón al Che Guevara y aquella carta a Roberto Fernández Retamar donde decía que le gustaba de ella lo martiniano y no lo marxista, la Revolución cubana está ausente en su obra" (299). Cabrera Infante en su exilio londinense era un buen barómetro de la actitud de los escritores de esa época. Mientras que Cortázar y García Márquez lo evitaban o repudiaban porque temían la censura de Castro, Paz y Vargas Llosa lo incluían y defendían: Cabrera Infante iba a ser un importante colaborador de la revista Plural.

En este aciago año lo más importante para Paz fue la masacre de estudiantes en Tlatelolco el 2 de octubre y su renuncia a la embajada en la India dos días más tarde. CDM hace ver que ya pensaba renunciar en agosto, días en los que ya considera, según le escribe a Tomlinson, que hay en México una represión "severa, brutal", y es en agosto que escribe su famoso poema "México: Olimpiada del 68" (309). Según Enrique Krauze, citado por CDM, la renuncia de Paz es '“'su hora mejor', una decisión que puso 'un límite histórico al poder imperial de la Presidencia de México', uno de esos momentos que lo convirtieron, a cabalidad, en 'un hombre en su siglo', el ciudadano que toma la decisión más sabia en la circunstancia más ardua" (312). De allí en adelante, Paz se convierte, si no en un opositor, en un severo crítico del poder omnívoro del PRI, y de los abusos "patrimonialistas" de ese "ogro filantrópico" que verá en el Estado mexicano, tal como lo expresa en el ensayo epó- 
nimo de su famoso libro de 1979. ${ }^{23}$ En 1971, ya de vuelta en México, inaugurará su revista Plural, cuyo mero nombre es indicativo. CDM es un niño de nueve años cuando se inaugura Plural, y para describir el desarrollo de esta primera revista él se apoya en el excelente libro de John King. ${ }^{24}$ Una notable prueba de la orientación de Plural es el tratamiento que hace de la literatura cubana. "Paz, contra Cortázar y García Márquez, apostó por disidentes cubanos de distinto perfil pero ambos insobornables, como Cabrera Infante y Sarduy" (353). Plural también "se distinguió por escandalizar dándole voz a los disidentes del Este, empezando por Solzhenitsyn, cuyo Archipiélago Gulag (1973) tuvo en el director de Plural un defensor apasionado pese a las agudas diferencias que tenía con el cristiano ruso" (358). Plural fue en América Latina una revista de importancia comparable en esa época sólo con Sur en Argentina. Fue abruptamente cerrada en 1976 por su patrocinador, el diario Excelsior (360).

\section{LA JEFATURA ESPIRITUAL}

CDM habla de la "jefatura espiritual" que Paz va asumiendo en México. Su genio, dice CDM, "pertenece a una especie rara, la de los poetas-críticos... Sólo W. B. Yeats, Valéry, Pound, Eliot, me parece a mí, comparten con Paz esa conjunción de hondura analítica y grandeza poética. Los cuatro fueron tan influyentes como ensayistas que como poetas y es imposible disociar, en ellos, a la prosa del verso" (411). Para CDM, los cinco pasaron a ser "jefes espirituales" en sus países: no sólo "organizadores públicos o privados de la cultura como editores litera-

${ }^{23}$ El ogro filantrópico (México: Joaquín Mortiz, 1979). Se equivoca, eso sí, quien piense que este libro de ensayos diversos representa un vuelco a la derecha. Basta leer, por ejemplo, "Los centuriones de Santiago" (271-277), donde, en lenguaje muy gráfico, sigue "empatando" a Estados Unidos con la Unión Soviética. Así el golpe pinochetista del 11 de septiembre ocurre "mientras Nixon se lava las manos sucias de Watergate en el lavamanos ensangrentado que le tiende Kissinger, mientras Brejnev inaugura nuevos hospitales psiquiátricos para disidentes inestables..." (El ogro, 271).

${ }^{24}$ John King, The Role of Mexico's Plural in Latin American Literary and Political Culture. From Tlatelolco to the "Philanthropic Ogre" (New York: Palgrave Macmillan, 2007). Publicado en español como Plural en la cultura politica latinoamericana. De Tlatelolco a "El ogro filantrópico" (México: Fondo de Cultura Económica, 2011). 
rios o promotores del teatro, sino figuras públicas, hombres políticos, poetas exotéricos y clérigos dispuestos a dar la batalla por un conjunto de verdades universales y trascendentes: verdaderos intelectuales" (411). CDM cree que no por nada tres de ellos obtuvieron el Nobel y que los otros dos lo habrían recibido si no hubiera sido por circunstancias particulares (411). En eso Paz se diferencia, claro, de otros poetas de habla española. Vallejo y Neruda tenían posiciones políticas fuertes pero no tenían dotes de ensayista: nadie los consultaría por su pensamiento filosófico o político, que en el caso de Neruda se limitaba - por lo menos en público- a las burdas consignas del PC. De allí también que se justifican, sobre todo en México, las largas páginas que CDM le dedica al pensamiento político de Paz.

Pero leyendo bien al biógrafo, uno se pregunta si las vicisitudes políticas de Paz y la imagen que había de él en los combates entre izquierdistas y derechistas tenían que ver con posturas reales o con chismografía político-literaria en el envidioso mundo intelectual de México. No hay duda de que El ogro filantrópico, editado en 1979, es un libro que va a molestar a la izquierda al denunciar los excesos del Estado mexicano. Pero ese mismo libro contiene ensayos en que Paz condena a Pinochet, o, más significativo aún, ensayos en que elogia a Fourier y su utopía donde "todos son sujetos libres consagrados 'al amor y el gusto, la comunión y el convivio, la Erótica y la gastrosofía"' (403); ensayos que por lo menos hoy cabrían perfectamente en la ideología utopista de la actual izquierda romántica. Parece ser que la izquierda mexicana se molestaba con Paz no tanto por sus ideas como por sus posiciones frente a Cuba o la disidencia soviética, y, más aún, por ciertas decisiones que tomó como, por ejemplo, la de aparecer en programas de televisión privada, que en ciertos círculos de México era un pecado mortal. "No estoy cerca del poder ni de Televisa", tuvo que decir, tras aparecer en un programa de un canal de esa empresa, explicando que no era más que un medio de comunicación (394). Claro que CDM sí va demostrando que Paz se va acercando, un poco, al poder, haciéndose incluso amigo de un empresario como Emilio Azcárraga, dueño de Televisa (494), a medida en que, a la vez, va perdiendo su "fobia antiempresarial" (393). Del Paz de los años 90, CDM llega a decir que "el trato con empresarios le había dado... un aire de mundanidad, nuevo en él" (494). Es obvio que eso tenía que haber molestado mucho a la izquierda. 
En este último período de la evolución política de Paz, CDM se detiene en tres importantes hitos: su crítica al sandinismo en 1984, que provoca que Paz sea quemado en efigie; la discutida elección de Carlos Salinas de Gortari en 1988, cuando éste casi empató con Cuauhtémoc Cárdenas en una contienda en que parecía haber fraude; y la irrupción, en Chiapas, a comienzos de 1994, del Subcomandante Marcos y sus enardecidos zapatistas.

La crítica al sandinismo Paz la hace en plena guerra nicaragüense, cuando recibe el Premio de la Paz de los libreros de la feria de Frankfurt. El discurso correspondiente es transmitido por Televisa, lo que agrava la ofensa. Dice Paz que "los actos del régimen sandinista muestran su voluntad de instalar en Nicaragua una dictadura burocrático-militar según el modelo de La Habana". Y siempre fiel a su práctica cautelosa de distinguir entre una buena idea original y su mala ejecución, como todavía lo hace en esa época con el socialismo, agrega que "así se ha desnaturalizado el sentido original del movimiento revolucionario" (427). Dice CDM que "el discurso de Frankfurt encendió los ánimos como ninguna otra declaración hecha por escritor alguno en México y quizá en toda América Latina" (427). Como consecuencia, unas cinco mil personas marcharon con pancartas a la embajada de Estados Unidos en Ciudad de México, exigiendo la muerte de Paz. Llevaron un monigote de unos dos metros de altura como efigie de Paz. Dice CDM: "Mientras éste era bañado en gasolina y elevado sobre un grosero palo, se repetía en coro esta frase que lejos de ser una consigna política, parecía más bien un conjuro cantado alrededor de un tótem mítico: 'Reagan, rapaz, tu amigo es Octavio Paz"” (429).

No todos los amigos de Paz protestaron con suficiente indignación frente a este grotesco acto. Uno que guardó un ominoso silencio fue Carlos Fuentes, cuyas lealtades y convicciones tendían a estar subordinadas a sus intereses. Tal vez ese silencio haya contribuido - CDM lo insinúa (469) - a que Paz autorizara en 1988 la publicación en Vuelta de "La comedia mexicana de Carlos Fuentes", una devastadora demolición del novelista redactada por Enrique Krauze (465). Si bien Krauze dirigía la revista, nada salía sin el visto bueno de Paz.

El segundo hito político: el triunfo de Salinas sobre Cárdenas en 1988. CDM hace un largo análisis del caso. Es el año en que CDM se suma al consejo de redacción de Vuelta y conoce a Paz por primera vez. 
Hay muchos mexicanos razonables que creen que ha habido fraude y que las elecciones se deberían repetir. CDM es uno de ellos. Paz no: él apoya las reformas neoliberales que pretende hacer Salinas y cree que Cárdenas es una vuelta al pasado, además de que repetir las elecciones va a generar una peligrosa inestabilidad en el país. Muchos intelectuales están con Paz, incluso Héctor Aguilar Camín, quien en el pasado lo había criticado desde la izquierda, diciendo, famosamente, que Paz era tan derechista que estaba "a la derecha de sí mismo" (349). En el análisis de CDM, Paz prefiere, "en los célebres términos de Goethe, la injusticia al desorden" (457); prefiere la "moral de la responsabilidad" a la "moral de las convicciones" (456-457).

El tercer hito político: la irrupción del Subcomandante Marcos y su Ejército Zapatista de Liberación Nacional (EZLN) en Chiapas el primero de enero de 1994, justo cuando entraba en vigencia el Tratado de Libre Comercio con Estados Unidos (498). Paz escribe doce contundentes artículos sobre este tema entre 1994 y 1996, y CDM los analiza en profundidad. Es que a sus 80 años el EZLN le presenta inesperados dilemas a Paz. Es un movimiento revolucionario sin obvios ribetes marxistas, que apela a los valores de la verdadera revolución mexicana, la de los tiempos de Zapata, esa pasión del padre de Paz que el mismo Paz en gran medida heredó. Como Paz en su poesía y en muchos ensayos, el EZLN llama a un retorno, a una vuelta a un pasado edénico, el pasado de los orígenes. CDM, citando su diario personal de la época, se tienta, no sin razón, con incursiones psicoanalíticas: reflexiona que el padre de Paz, en parte amado y en parte rechazado por el hijo por el horror del alcoholismo, vuelve como fantasma, "en calidad de Comendador", trayéndole a sus 80 años, con impetuosa ironía, un regalo de cumpleaños: "el 30-30 que simboliza esta patria que creías perdida y olvidada" (504). Todo un desafío para Paz, dada la contradicción que hay entre su deseo de abrazar — y de que México abrace — la modernidad neoliberal de Salinas y su permanente nostalgia poética por esos orígenes primigenios que añora. Ese llamado a las raíces realizado por el EZLN es para Paz atractivo pero no lo es su violencia, su culto a la muerte (507). Por su parte, la represión que ordena Salinas es inaceptable, y Paz empieza a distanciarse de él (508). Con todo, en estos ensayos citados por CDM, Paz es siempre brillante, como cuando — crítico literario que es - analiza la retórica del Subcomandante Marcos: 
A diferencia del lenguaje burocrático de los líderes del PRI, el del subcomandante Marcos, aunque desigual y lleno de subidas y caídas como un tobogán de montaña, es imaginativo y veraz. Sus pastiches de lenguaje evangélico y, con más frecuencia, de la elocuencia indígena, con sus fórmulas recurrentes, sus metáforas y metonimias, son casi siempre afortunados. A veces es chabacano y chocarrero; otras brioso y elocuente, otras satírico y realista; otras machacón y sentimental. Una prosa accidentada: elevaciones y batacazos. Su fuerte no es el razonamiento, sino la emoción y la unción: el púlpito y el mitin. (515)

Así eran las intervenciones iluminadas del jefe espiritual en Vuelta, su gran revista, la que reemplazó a la igualmente notable Plural. Este hombre que cuando lo conocí en 1967-1968 estaba obsesionado con la falta de crítica en América Latina, permitió a través de su propia prosa - $y$ de sus revistas - que se estableciera una amplia tradición crítica en su país.

Lo que sí cabe dudar es cuánta crítica estaba dispuesto a aceptar el mismo Paz. Un hombre convertido en jefe espiritual no puede estar sino en una suerte de burbuja. En 1990, cuando Vuelta organizó un congreso internacional con el título "La experiencia de la libertad", llegó un impertinente Mario Vargas Llosa a probar la tolerancia a la crítica de Paz. Delante de las grandes figuras intelectuales de todo el mundo que se habían congregado en México, Vargas Llosa atacó el sistema político de sus anfitriones, tildando a México de "dictadura perfecta". La famosa escena está en You Tube, donde se ve a Paz escuchando a Vargas Llosa con manifiesto enojo. Paz, que llevaba años criticando al PRI y tratando de contribuir a que México tuviera un sistema más democrático, no toleró que un extranjero llegara a hablar así, sin por lo demás consultarlo, y rebatió a Vargas Llosa con una poco convincente distinción lingüística: México no tiene dictadura sino un "sistema hegemónico de dominación" (448).

Había límites también a lo que se podía admitir en cuanto a esa forma tan natural de la crítica que es el humor. Cuando estalla el EZLN, Guillermo Sheridan escribe para Vuelta un artículo humorístico. Titulado "Los diez días que conmovieron al rumbo", se ríe de lo complicado que es tener al zapatismo como sorpresivo enemigo. Paz prohíbe su publicación, explicándole a Sheridan que "la crónica era demasiado burlesca dada la gravedad de los acontecimientos" (504). 


\section{EL ENSAYISTA Y EL POETA}

Paz escribía mucha prosa. A veces se trataba de ejercicios periodísticos o reseñas de libros en Plural o Vuelta, a veces de ensayos de alto vuelo, como muchos de los que están recogidos en El arco y la lira o Los hijos del limo ${ }^{25}$. A veces los dos tipos de escritura están mezclados en un solo libro. Por ejemplo, en El ogro filantrópico nos encontramos con las hoy famosas reflexiones epónimas sobre los excesos del Estado mexicano, entremezcladas con escritos ocasionales de poca profundidad. Los mejores ensayos de Paz son los que meditan sobre la poética y la escritura, y esos son de alguna forma u otra ecos de sus poesías. Son estos ensayos, quizás, los que le permiten a CDM afirmar que no se puede apreciar plenamente los poemas de Paz "sin recurrir a su poética" y que "en Paz una comprensión a profundidad exige considerar todas sus visiones como una obra indivisible" (555). En realidad, es difícil encontrar descripciones más precisas de la poética de Paz que en los ensayos de El arco y la lira, donde el acto de escribir un poema es equiparado al acto sexual en su búsqueda de instantes de éxtasis. Por ejemplo, en "Poesía y poema", el primer ensayo de ese libro, escribe Paz: "En el acto amoroso la conciencia es como la ola que, vencido el obstáculo, antes de desplomarse se yergue en una plenitud en la que todo - forma y movimiento, impulso hacia arriba y fuerza de gravedad - alcanza un equilibrio sin apoyo, sustentado en sí mismo. Quietud del movimiento. $\mathrm{Y}$ del mismo modo que, a través de un cuerpo amado entrevemos una vida más plena, más vida que la vida, a través del poema vislumbramos el rayo fijo de la poesía. Ese instante contiene todos los instantes. Sin dejar de fluir, el tiempo se detiene, colmado de sí". ${ }^{26}$ La poesía de Paz está en busca permanente del instante en que la ola sigue erguida, antes de desplomarse.

Un estilo lapidario el de Paz en sus mejores ensayos, un estilo sentencioso, de vate que dicta cátedra. Un estilo que estimula, que despierta la imaginación, pero que no pretende exhibir verdades científicas. CDM tiene razón en recordarnos que Paz es ante todo un poeta. No es un filósofo. Como poeta se puede permitir muchas licencias, sin pretender llegar a una filosofía coherente (556). Se permite ser "desdeñoso de

\footnotetext{
${ }^{25}$ Barcelona: Seix Barral, 1974.

${ }^{26} \mathrm{El}$ arco, 25
} 
la erudición excesiva", incluso cuando escribe un libro inmenso como Sor Juana Inés de la Cruz o las trampas de la $f e^{27}$, donde como dice CDM — sin ironía intencional — "no necesitó de muchos libros para dibujar su cuadro de la Nueva España" (418). Paz en realidad desplegaba erudición con el aplomo del poeta: uno sospechaba que muchos de los autores que citaba los había picoteado más que leído a fondo: no importaba tanto porque todo lo que decía de ellos era interesante. Escribió sin pudor un libro sobre Lévi-Strauss, Claude Lévi-Strauss o el nuevo festín de $E_{\text {sopo }}{ }^{28}$, pero ¿cuánto de verdad leyó de la larga y compleja obra del antropólogo francés? CDM cita una descripción que hace Elena Paz Garro, la hija de Paz, del poeta leyendo. Según ella, él "acomodaba los libros en un montón enorme, junto a su sillón, los tomaba, y uno por uno, hojeaba dos o tres páginas y exclamaba en voz alta: ¡Leído! Sólo si le gustaba mucho un poema del libro que estaba 'leyendo', nos lo repetía en voz alta dos o tres veces. 'QQué maravilla es Li Po!', exclamaba, y tomaba otro libro" (226). CDM demuestra con abundante evidencia que ni Elena Paz Garro ni su mamá Elena (o Helena) son testigos muy confiables, pero algo de verdad puede haber en este testimonio aunque sea como metáfora de los picoteos de poeta que hace Paz al leer. Según CDM, fue lector de Rawls y Nozick, pero se me ocurre que, si lo fue, depende de cómo se define "leer". Dice CDM que "el incrédulo Paz leyó a Rawls pero no le convenció, le pareció admirable como una catedral gótica, entró y se salió [sic]. ¿Nozick? Un palacio de cristal, me imagino: translúcido y helado. Tan inhabitable que el propio teórico libertario abandonó su construcción [sic]" (547).

Son instantes en que CDM se deja ir, suspendiendo su propio juicio crítico. Pero él está consciente de que la liviandad olímpica con que Paz se pasea por algunos temas es susceptible de ser criticada, sobre todo cuando cae en manos de algún exponente de la aterrizada cultura anglosajona. CDM se detiene largamente en un ensayo de Michael Wood, publicado en mayo de 1974 en el New York Review of Books sobre Children of the Mire, el título que se le da en inglés a Los hijos del limo (373-374). ${ }^{29}$ "A veces juguetón, a veces ampuloso, cosmopolita

${ }^{27}$ México: Fondo de Cultura Económica, 1982.

${ }^{28}$ México: Joaquín Moriz, 1967.

${ }^{29}$ Michael Wood, "Children of the Mire: Modern Poetry from Romanticism to the Avant-Garde", New York Review of Books, mayo 16, 1974: 186. 
y provinciano, lúcido y confuso, valiente y evasivo, Octavio Paz es la idea platónica del intelectual latinoamericano, y no es el menor de sus logros haber llenado con encanto, distinción e ironía ese difícil y agotador papel. Porque el intelectual en América Latina es crítico, payaso, sacerdote, agitador social y maestro de escuela: todo al mismo tiempo, 'un hombre para todas las estaciones'. Debe evaluar el pasado, mofarse del presente, bendecir a los nuevos movimientos artísticos y literarios, alentar con discreción el tipo correcto de revolución y componer cartas rituales de recomendación para su país y sus compatriotas. Entre otras cosas. Lo que es sorprendente de Paz no es que haya escrito disparates en los últimos años, sino que no haya hecho algo peor que eso; y lo que es aún mejor, el que haya escrito mucha poesía que está lejos de ser un disparate" (374).

Con todo, Paz en sus ensayos es deslumbrante y memorable. Como lo señala $\mathrm{CDM}$, hace comparaciones estimulantes: que un erudito después las estudie y determine si son veraces o razonables. Comparaciones como la que hace entre Picasso y Duchamp. "Picasso", dice, "ha hecho visible nuestro siglo; Duchamp nos ha mostrado que todas las artes, sin excluir a la de los ojos, nacen y terminan en una zona invisible" (276). Gran crítico de arte, Paz publicará en 1968 un interesante libro sobre Duchamp, un libro objeto o "libro maleta" que lleva textos y láminas guardadas en una "maleta" de cartón. ${ }^{30}$ Como dice CDM, Paz tiene en sus ensayos una incomparable "capacidad combinatoria", una que genera un deslumbrante "caos creador" (285).

Pero finalmente no hay nada en Paz como su poesía. Es una poesía fina, delicada, difícil de lograr porque no descansa en metáforas llamativas. A veces en sus búsquedas de trascendencia está compuesta nada más que de palabras abstractas que embrujan por la forma en que están combinadas y por la música que se logra extraerles: en eso recuerda la poesía de San Juan de la Cruz. Como en la poesía de San Juan, hay una dualidad cuerpo/alma, una lucha entre los dos, pero a diferencia del monje carmelita que quiere liberarse de su cuerpo para que viva en plenitud eterna su alma, en Paz es al revés: si no el alma, es la conciencia, el superego, la culpa lo que quiere destronar para que prospere en plenitud el cuerpo en el éxtasis de la cópula. A menudo como en

${ }^{30}$ Marcel Duchamp o el castillo de la pureza (México: Ediciones Era, 1968). 
"Blanco", ese gran poema largo que, como la Rayuela de Cortázar, está hecho para ser leído en distintas secuencias y combinaciones, esta poesía abstracta de Paz está, como vimos antes, entremezclada con escenas eróticas extremadamente sensuales, y las oscilaciones entre concepto y cuerpo, a veces inesperadas, son siempre bien logradas por la música en que están insertas y porque no son gratuitas: tienen siempre su razón de ser.

A diferencia de Neruda, Paz disfruta mucho de sus experiencias orientales e incorpora la sabiduría india a sus propias búsquedas metafísicas. Pero lo hace con un sano escepticismo, esa dimensión crítica que él siempre buscaba: hay, hemos visto, tremendas generalizaciones en sus ensayos, pero éstas tienen sus contrapuntos; frente a una generalización a menudo hay otra que la contradice, y es así en la poesía. Como en "Vrindaban"31, donde un sabio hindú es invocado en apoyo a la búsqueda que siempre hace el poeta de "hendiduras", formas femeninas escondidas, las que se podrían encontrar en una roca por ejemplo, aperturas que permiten que la dura roca viva y respire, y que, una vez despierta a la cópula, genere la creación de un poema. Pero ese sabio tan paziano es a la vez pícaro, quien sabe si incluso un farsante cuyas visiones son a lo mejor el producto de una droga.

Ido ido

Santo pícaro santo

Arrobos del hambre o de la droga

Tal vez vio a Krishna

Árbol azul y centelleante

Nocturno surtidor brotando en la sequía

Tal vez en una piedra hendida

Palpó la forma femenina

Y su desgarradura

El vértigo sin forma

Por esto o aquello

Vive en el muelle donde queman a los muertos ${ }^{32}$

\footnotetext{
${ }^{31}$ Paz, Ladera este, 57-63.

${ }^{32}$ Ibídem, 30.
} 
Los poemas orientales de Paz a veces se limitan a observaciones de viajero, retratos pasajeros de escenas memorables. Como en "El día en Udaipur"33, las líneas mágicas:

Con un traje alquilado

el niño va a su boda.

O más adelante:

En el islote chillan

Monos de culo rojo. ${ }^{34}$

Después, de viajero en Kabul con Marie José, en "Viento entero"35, observaciones llamativas como:

El bazar tornasolea

Timbres motores radios

El trote pétreo de los asnos opacos

Cantos y quejas enredados

Entre las barbas de los comerciantes

Alto fulgor a martillazos esculpido ${ }^{36}$

Y allí mismo en Kabul para el viajero erudito que quiere saber algo de historia, unas líneas terribles:

Nosotros nos roemos los codos

En los jardines de su alcázar de estío

Tipú Sultán plantó el árbol de los jacobinos

Luego distribuyó pedazos de vidrios

Entre los oficiales ingleses prisioneros

Y ordenó que se cortasen el prepucio

Y se lo comiesen ${ }^{37}$

\footnotetext{
${ }^{33}$ Ibídem, 25-28.

${ }^{34}$ Ibídem, 26.

${ }^{35}$ Ibídem, 101-8.

36 Ibídem, 101-2.

${ }^{37}$ Ibídem, 103.
} 
Viaja y viaja el poeta y, como Góngora en sus "Soledades", viaja a través de las palabras en búsqueda de alguna otra orilla: una que esté "más allá de mí mismo", piensa, al observar Delhi — “vieja Delhi fétida Delhi"— en "El balcón"38:

\section{Lejanías}

pasos de un peregrino son errante

sobre este frágil puente de palabras

La hora me levanta

hambre de encarnación padece el tiempo

Más allá de mí mismo

en algún lado aguardo mi llegada ${ }^{39}$

En este Delhi físico que tan fácilmente se desliza a lo metafísico, conoce a gente de carne y hueso que describe con un notable talento de retratista que posee, y que comparte con algunos poetas americanos como Robert Lowell, a quien Paz conoció y admiró mucho. Así el poema que se llama "White Huntress". Lo cito entero:
No lejos del dak bungalow, entre bambúes y yerbales, tropecé con Artemisa.
Iba armada de punta en blanco:
Un cooli cargaba el Holland and Holland, otro el vanity case y la maleta con los antibióticos y los preservativos. ${ }^{40}$

\section{CDM Y PAZ}

Me he detenido en algunos de estos versos extraordinarios porque siento que CDM no lo hace lo suficiente. No nos levanta a Paz el poeta tanto como él se lo merecería; pero hemos dicho que esto es seguramente por ser ésta una biografía para iniciados que ya conocen los versos de Paz de memoria, o casi. Donde sí es inigualable CDM es

${ }^{38}$ Ibídem, 11-6.

${ }^{39}$ Ibídem, 16. "Pasos de un peregrino son errante" es la primera línea de las "Soledades" de Góngora.

${ }^{40}$ Ibídem, 29. 
en aquellas escenas en que él está presente, donde actúa como testigo directo, como cuando describe reuniones del consejo de redacción en que él participa. Es allí donde vemos al monarca benévolo de cerca. El algún momento, José María Espinasa le dice "maestro" y Paz le pide que lo llame Octavio, que si no, "no vuelvo a estas reuniones". ${ }^{41}$ Claro que este "Octavio" es siempre el jefe, el jefe espiritual: siempre tiene la última palabra, y los demás en torno a este monarca son cortesanos. Lo que no significa que el monarca no empodere a los demás. CDM disfruta de ese poder, se siente como parte de un grupo excepcional, uno que está haciendo historia. "Si por corte se entiende ese ambiente sobreactuado y fascinante de quienes han sido educados en la ilusión de vivir la historia del mundo como propia, sí éramos una corte, es decir una polis dentro de la polis, formada en torno a la gravedad de un jefe espiritual" (540). Con franqueza casi ingenua, CDM nos está confesando lo bien que se sentían estos jóvenes al pensar que estaban haciendo historia con Paz.

Lamentablemente todo llega a su fin: llega el día en que el rey se tiene que morir. "Octavio Paz murió poco después de las 10:30 de la noche del domingo 19 de abril de 1998 (el mismo día que Lord Byron)", sentencia CDM (568). El deceso lo anuncia poco después, el propio Presidente Zedillo (568), convertido a estas alturas en un miembro más de la corte del monarca. Las descripciones de CDM aquí son sublimes, como la que hace de la despedida de Paz, cuando convoca a todos sus amigos a su casa. Para todos les tiene reservada alguna frase, a veces dura. En cuanto a su propia muerte, dice "no creo en la trascendencia". Parece que le bastó aquella que buscaba en su poesía. "Seré ese vaso de agua que me estoy tomando", explica, sereno, con el vaso en la mano. "Seré materia" (566).

$\mathrm{CDM}$ agrega que alguien se llevó aquel vaso como reliquia. "No era para menos; ese vaso quedaba como una suerte de Santo Grial de la poesía mexicana" (566). Santo Grial que ha encontrado en CDM un digno guardián. $E P$

41 Al comienzo, al conocerlo, cometí el error - muy chileno- de decirle "Don Octavio". Me objetó que eso sonaba a comedia de capa y espada. 